\title{
THE KIDNEY FUNCTION IN UREA-LOADED SHEEP FED A HIGH PROTEIN DIET
}

\author{
K. BOLDIŽÁROVÁ, Š. FAIX, L. LENG \\ Institute of Animal Physiology, Slovak Academy of Sciences, Košice, Slovak Republic
}

Received July 16, 1999

Accepted August 23, 1999

\section{Abstract}

Boldižárová K., Š. Faix, L. Leng: The Kidney Function in Urea-loaded Sheep Fed a High Protein Diet. Acta Vet. Brno 1999, 68: 185-190.

The objectives of this experiment were to investigate the effects of the increased plasma urea concentration induced by its intravenous infusion on the renal functions, especially on the glomerular filtration rate (GFR), in sheep that do not produce hypertonic urine during intake of a high protein diet. The young ewes of b.w. 22 to $25 \mathrm{~kg}$ were kept on a diet with the daily intake $129.3 \mathrm{~g}$ of crude protein and $12.03 \mathrm{MJ}$ of digestible energy for at least 3 weeks before the renal function measurements. During clearance protocol, the plasma urea level was increased almost threefold in comparison to the baseline values by an infusion into the jugular vein (from $5.67 \pm 0.48$ $\mathrm{mmol} \cdot \mathrm{l}^{-1}$ to $\left.15.70 \pm 0.79 \mathrm{mmol} \cdot \mathrm{l}^{-1}, \mathrm{P}<0.001\right)$. The urea load had no effects on the urine flow rate (control vs. urea infused animals, $3.07 \pm 0.41$ vs. $2.40 \pm 0.23 \mathrm{ml} \cdot \mathrm{min}^{-1}$, NS) nor the GFR $(81.43$ \pm 8.14 vs. $77.48 \pm 5.43 \mathrm{ml} \cdot \mathrm{min}^{-1}$, NS). Obviously, both the urea concentration in urine $(79.84$ \pm 17.16 vs. $\left.243.22 \pm 18.94 \mathrm{mmol} \cdot \mathrm{l}^{-1}, \mathrm{P}<0.001\right)$ and the amount of urea excreted $(198.78 \pm 9.17$ vs. $\left.586.60 \pm 69.69 \mu \mathrm{mol} \cdot \mathrm{min}^{-1}, \mathrm{P}<0.001\right)$ together with the clearance of osmotically active substances $\left(1.87 \pm 0.11\right.$ vs. $\left.3.85 \pm 0.52 \mathrm{ml} \cdot \mathrm{min}^{-1}, \mathrm{P}<0.01\right)$ were found to be significantly elevated in the urea-loaded group. The amount of urea reabsorbed was highly significantly larger due to urea load $\left(245.22 \pm 34.55\right.$ vs. $\left.636.02 \pm 67.17 \mu \mathrm{mol}^{\circ} \mathrm{min}^{-1}, \mathrm{P}<0.001\right)$ while no changes in the fractional urea excretion $(47.26 \pm 4.23$ vs. $47.49 \pm 3.34 \%$, NS) nor in the urea clearance $(36.20 \pm 2.16 \mathrm{vs}$. $36.80 \pm 3.52 \mathrm{ml} \cdot \mathrm{min}^{-1}, \mathrm{NS}$ ) were observed. The presented results demonstrate that kidneys of sheep producing rather hypotonic urine during intake of a high-protein diet do not respond to the intravenous urea load with a rise in the GFR nor by a change in the urea clearance.

Sheep, kidney, GFR, urea

The ability of ruminants fed a low protein intake to considerably increase the renal urea reabsorption for its subsequent recycling through the digestive tract is well known. It has been shown in sheep that a significant reduction of the glomerular filtration rate (GFR) is main factor responsible for this phenomenon called the renal urea retention (Leng et al. 1985; Cirio and Boivin 1990). On the other hand, the supply of full milk diet with an additional protein to calves during neonatal period (Skrzypczak et al. 1996) or the administration of casein hydrolysate into abomasum of sheep on a low protein diet (Szanyiová et al. 1996) increases the GFR like in simple-stomach animals (Lee and Summerill 1982).

Data from the experiments on simple-stomach animals shows that many possible mediators of the protein intake or rather amino acid-induced rise in renal haemodynamics, like glucagon (Hirschberg et al. 1988), liver-borne factor (Lang et al. 1991), cAMP (B ankir et al. 1997) and others have been proposed. A completely opposite renal response to glucagon was found in sheep. Systemic or intraportal infusion of glucagon significantly reduced both the GFR and the urine flow rate (Faix et al. 1994; Faix and Leng 1997). It has been summarized (Bankir et al. 1996) that a chronic stimulation of the urinary concentrating activity with protein intake or the chronic administration of vasopressin led to similar specific changes in renal morphology and functions, mainly to the increased GFR in

Address for correspondence: RNDr. Klaudia Boldižárová Institute of Animal Physiology Šoltésovej 4, 04001 Košice, Slovak Republic
Phone: ++421956332048

Fax: ++421 $95762162 ; 764535$

http://www.vfu.cz/acta-vet/actavet.htm 
animals with simple stomachs. In other words, they stated that the protein intake and vasopressin have the same or very similar effects on GFR which are mediated or induced by changes in the urinary concentrating ability of kidneys.

We have recently studied the kidney function in sheep with the long-term formation of highly concentrated urine and fed a high protein diet (Boldižárová et al. 1999). Contrary to animals with simple stomachs, the kidneys of sheep did not respond to a vasopressin-induced long-term formation of highly concentrated urine with a rise in the GFR. Interestingly, the plasma urea level was found to be somewhat but significantly higher in animals treated with vasopressin analogue.

The objectives of this experiment were to investigate the effects of the increasing of plasma urea concentration by its intravenous infusion on the renal function, especially on the GFR, in sheep which do not produce a hypertonic urine during intake of a high protein diet.

\section{Materials and Methods}

The experiment was performed on young ewes (Ovis aries) of Merino breed weighing from 22 to $25 \mathrm{~kg}$. The sheep were housed individually in cages with free access to water and minerals. The animals were fed a high protein diet for at least 3 weeks before the measurements of the kidney function. The total daily ration for each sheep consisted of $500 \mathrm{~g}$ of hay, $300 \mathrm{~g}$ of barley and $250 \mathrm{~g}$ of wheat bran providing $129.25 \mathrm{~g}$ of crude protein and 12.03 $\mathrm{MJ}$ of digestible energy. The renal functions were measured by a standard clearance technique on conscious sheep fixed in cages. The right jugular vein was cannulated with a polyethylene capillary (o.d. $1.1 \mathrm{~mm}$; i.d. $0.7 \mathrm{~mm}$ ) for the infusions. The experimental group of animals $(n=8)$ received intravenously the priming solution $(1 \mathrm{~g}$ of pyrogen-free inulin and $8.1 \mathrm{~g}$ of urea in $200 \mathrm{ml}$ of sterile $0.15 \mathrm{~mol} \mathrm{NaCl})$ and then a continuous infusion $(6.6 \mathrm{mg}$ of inulin and $40 \mathrm{mg}$ of urea $\mathrm{ml}^{-1} \cdot \mathrm{min}^{-1}$ ) was initiated. The larger volume of priming dose was preferred to avoid haemolysis due to high urea content. The control group $(\mathrm{n}=8)$ was given just inulin in $0.15 \mathrm{~mol} \mathrm{NaCl}$ for both priming dose and infusion. The blood was sampled from contralateral jugular vein. The urine was quantitatively collected into calibrated glass cylinders through a Foley catheter (French size 14) placed in the urinary bladder.

The first collection period of urine began $90 \mathrm{~min}$ after the start of infusion to allow the equilibration of administered substances in the extracellular space. Each collection period lasted $30 \mathrm{~min}$. Blood samples were collected into heparinized tubes at the mid-point of every urine collection period. Three collection periods were carried out in each sheep. The results from the three consecutive periods in the same animal were averaged because there were no significant changes in the values of all the parameters measured.

The concentrations of inulin (Vurek and Pegram 1966) and urea (Leng et al. 1986) were determined in the plasma and urine samples by fluorometric methods. The osmolality of plasma and urine was determined cryoscopically on the Knauer osmometer. The plasma and urine levels of sodium, potassium, calcium, and magnesium were determined on the Perkin Elmer atomic absorption spectrophotometer.

The statistical analysis of the differences between the control and the urea-loaded groups was performed by Student's $t$-test. The results are given as the means \pm SEM.

\section{Results}

The infusion of urea into jugular vein of the sheep fed a high protein diet resulted in almost threefold increase of the urea concentration in blood plasma $\left(\mathrm{P}_{\text {urea }}\right.$, from $5.67 \pm 0.48$ to $\left.15.70 \pm 0.79 \mathrm{mmol} \cdot \mathrm{l}^{-1}, \mathrm{P}<0.001\right)$. The glomerular filtration rate (GFR, $81.43 \pm 8.14$ in control vs. $77.48 \pm 5.43$ in urea loaded sheep, $\left.\mathrm{ml} \cdot \mathrm{min}^{-1}, \mathrm{NS}\right)$ and urine flow rate $(\mathrm{V}, 3.07$ \pm 0.41 vs. $2.40 \pm 0.23 \mathrm{ml} \cdot \mathrm{min}^{-1}, \mathrm{NS}$ ) were not found to be influenced by a high plasma urea level. The urea concentration of urine was significantly elevated $\left(\mathrm{U}_{\text {urea }}\right.$, from $79.84 \pm 17.16$ to $\left.243.22 \pm 18.94 \mathrm{mmol} \cdot \mathrm{l}^{-1}, \mathrm{P}<0.001\right)$ in the urea-infused sheep but without any change in the urea clearance $\left(\mathrm{C}_{\text {urea }}, 36.20 \pm 2.16\right.$ vs. $36.80 \pm 3.52 \mathrm{ml} \cdot \mathrm{min}^{-1}$, NS). Both the amount of urea excreted $\left(\mathrm{U}_{\text {urea }} \mathrm{V}, 198.78 \pm 9.17\right.$ vs. $\left.586.60 \pm 69.69 \mu \mathrm{mol} \cdot \mathrm{min}^{-1}, \mathrm{P}<0.001\right)$ as well as the renal urea reabsorption $\left(\right.$ Reab $_{\text {urea }}, 245.22 \pm 34.55$ vs. $636.02 \pm 67.17 \mu \mathrm{mol} \cdot \mathrm{min}^{-1} \mathrm{P}<$ $0.001)$ were significantly higher due to urea load while the fractional excretion of urea $\left(\mathrm{FE}_{\mathrm{urea}}, 47.26 \pm 4.23\right.$ vs. $47.49 \pm 3.34 \%$, NS) was not influenced (Fig. 1).

The plasma levels of sodium $\left(147.44 \pm 1.19 \mathrm{vs} .147 .13 \pm 1.16 \mathrm{mmol} \cdot \mathrm{l}^{-1}, \mathrm{NS}\right)$ and calcium $\left(2.55 \pm 0.04\right.$ vs. $2.53 \pm 0.25 \mathrm{mmol} \cdot \mathrm{l}^{-1}$, NS) were stable, with no significant differences between the control and urea-infused groups. The potassium level in plasma (3.99 $\pm 0.11 \mathrm{vs.}$ 


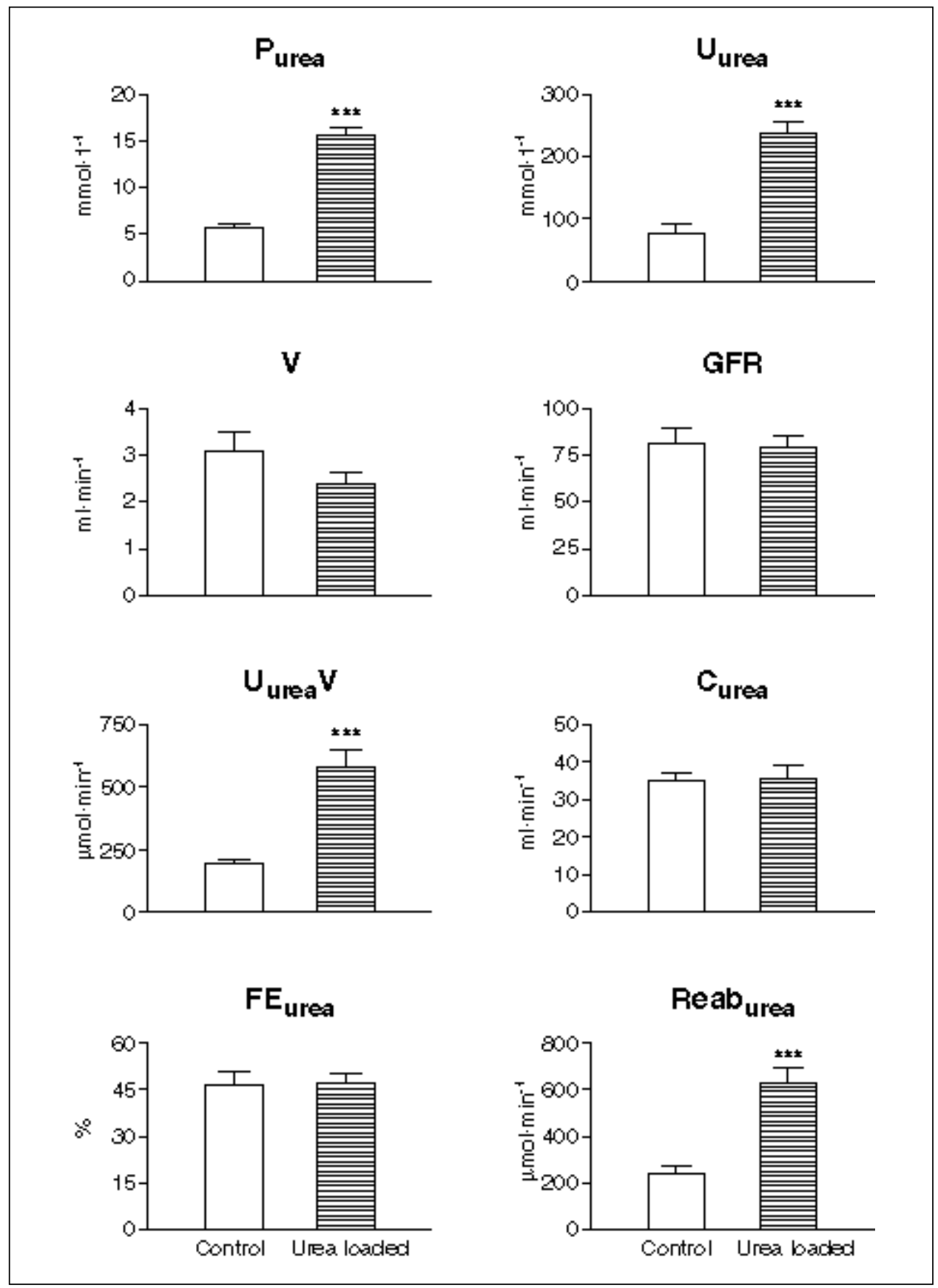

Fig. 1. The effects of the intravenous urea infusion on the plasma $\left(\mathrm{P}_{u r e a}\right)$ and urine urea concentrations $\left(\mathrm{U}_{\text {urea }}\right)$, urinary flow rate $(V)$, glomerular filtration rate $(G F R)$, amount of urea excreted $\left(U_{u r e a} V\right)$, renal clearance of urea $\left(\mathrm{C}_{\text {urea }}\right)$, fractional urea excretion $\left(\mathrm{FE}_{\text {urea }}\right)$ and on the amount of urea reabsorbed $\left(\mathrm{Reab}_{\text {urea }}\right)$ in sheep fed a high protein diet. Values are means \pm SEM, $n=8$ for each group. Significance: $* * *=P<0.001$. 
$\left.3.53 \pm 0.12 \mathrm{mmol} \cdot \mathrm{l}^{-1}, \mathrm{P}<0.05\right)$ was found to be slightly but significantly decreased while the plasma level of magnesium $\left(0.90 \pm 0.02\right.$ vs. $\left.1.00 \pm 0.02 \mathrm{mmol} \cdot \mathrm{l}^{-1}, \mathrm{P}<0.01\right)$ was higher due to urea load.

The data dealing with the excretion of electrolytes and the osmolality parameters is summarized in Table 1. The intravenous urea load resulted in significant increase of both the amount of sodium excreted and the fractional excretion of sodium. On the other hand, the fractional excretion of magnesium was found to be reduced. No differences were found in the excreted amounts of potassium, calcium and magnesium.

\section{Table 1}

The effects of the intravenous urea load on the amount of electrolytes excreted $\left(U_{x} V\right)$, the fractional excretion of electrolytes $\left(\mathrm{FE}_{\mathrm{X}}\right)$, plasma $\left(\mathrm{P}_{\mathrm{osm}}\right)$ and urine $\left(\mathrm{U}_{\mathrm{osm}}\right)$ osmolality and on the osmotic clearance $\left(\mathrm{C}_{\mathrm{osm}}\right)$ in sheep fed a high protein diet. Values are means \pm SEM.

\begin{tabular}{|l|c|c|c|}
\hline & $\begin{array}{c}\text { Control } \\
(\mathbf{n = 8})\end{array}$ & $\begin{array}{c}\text { Urea loaded } \\
(\mathbf{n = 8})\end{array}$ & \\
\hline $\mathrm{U}_{\mathrm{Na}} \mathrm{V}\left(\mu \mathrm{mol} \cdot \mathrm{min}^{-1}\right)$ & $5.60 \pm 1.32$ & $75.70 \pm 20.05$ & $\mathrm{P}<0.01$ \\
\hline $\mathrm{U}_{\mathrm{K}} \mathrm{V}\left(\mu \mathrm{mol} \cdot \mathrm{min}^{-1}\right)$ & $170.80 \pm 9.35$ & $216.18 \pm 31.35$ & $\mathrm{NS}$ \\
\hline $\mathrm{U}_{\mathrm{Ca}} \mathrm{V}\left(\mu \mathrm{mol} \cdot \mathrm{min}^{-1}\right)$ & $2.15 \pm 0.34$ & $2.02 \pm 0.38$ & $\mathrm{NS}$ \\
\hline $\mathrm{U}_{\mathrm{Mg}} \mathrm{V}\left(\mu \mathrm{mol} \cdot \mathrm{min}^{-1}\right)$ & $15.29 \pm 1.13$ & $12.64 \pm 1.48$ & $\mathrm{PS}$ \\
\hline $\mathrm{FE}_{\mathrm{Na}}(\%)$ & $0.05 \pm 0.02$ & $0.62 \pm 0.14$ & $\mathrm{NS}$ \\
\hline $\mathrm{FE}_{\mathrm{K}}(\%)$ & $55.29 \pm 3.86$ & $81.02 \pm 12.19$ & $\mathrm{NS}$ \\
\hline $\mathrm{FE}_{\mathrm{Ca}}(\%)$ & $1.00 \pm 0.15$ & $1.10 \pm 0.20$ & $\mathrm{P}<0.05$ \\
\hline $\mathrm{FE}_{\mathrm{Mg}}(\%)$ & $22.29 \pm 2.01$ & $16.44 \pm 1.80$ & $\mathrm{P}<0.001$ \\
\hline $\mathrm{P}_{\mathrm{osm}}\left(\mathrm{mosm} \cdot \mathrm{kg}^{-1} \mathrm{H}_{2} \mathrm{O}\right)$ & $299.60 \pm 1.01$ & $308.00 \pm 1.26$ & $\mathrm{P}<0.01$ \\
\hline $\mathrm{U}_{\mathrm{osm}}\left(\mathrm{mosm} \cdot \mathrm{kg}^{-1} \mathrm{H}_{2} \mathrm{O}\right)$ & $232.31 \pm 60.69$ & $491.88 \pm 55.13$ & $\mathrm{P}<0.01$ \\
\hline $\mathrm{C}_{\mathrm{osm}}\left(\mathrm{ml} \cdot \mathrm{min}^{-1}\right)$ & $1.87 \pm 0.11$ & $3.85 \pm 0.52$ & \\
\hline
\end{tabular}

Obviously, the intravenous urea infusion led to a significant increase of the plasma and urine osmolality and consequently also to a larger clearance of osmotically active substances.

\section{Discussion}

Our investigation clearly shows that the acute intravenous infusion of urea does not affect the glomerular filtration rate nor the renal urea clearance in sheep fed a high protein intake. Stimulation of the urinary concentrating mechanism with protein intake is known to usually increase the GFR of simple-stomach animals (B ankir et al. 1996). Because urea is a final nitrogen product of the protein metabolism its plasma concentration and renal excretion are obviously dependent on the level of protein intake. It was a basic condition for this experiment to imitate the consequences of large protein intake by an acute urea load to sheep yet on a high protein diet. Our very recent results on sheep (long-term study) treated with a vasopressin analogue showed the plasma urea level to be increased by $26 \%$ only while the renal urea reabsorption was elevated by $63 \%$ (Boldižárová et al. 1999). This difference has been explained by a large urea recycling into the digestive tract. Despite of a three-fold increase of the plasma urea level, neither the GFR nor the renal urea clearance was changed in this experiment. It seems that not the plasma urea level itself but rather some by-products of the urea synthesis cycle might be involved in the GFR regulation in sheep (Leng et al. 1994).

However, there are striking differences in protein digestion and metabolism between animals with simple stomachs and ruminants. One of the main consequences of the similar increase in the GFR of simple stomach animals occurring with high protein intake is to limit 
the rise in plasma urea level that results from either the increased synthesis of urea by the liver or large renal tubular urea reabsorption. The adaptation ability in animals with simple stomachs is set to a need to increase the excretion of urea as a waste product of the protein metabolism (Bankir 1996) inducing a response of the renal urea clearance. On the other hand, in ruminants the presence of large microbial population in the forestomachs enhances their potential to utilize nitrogen sources, including ammonia arising from the recycling of endogenous urea. Thus the kidneys of ruminants contribute to the conservation mechanism of nitrogen for a potential proteosynthesis (Faix ová et al. 1998). This statement on the special role of the ruminant kidneys in nitrogen metabolism is supported also by an unaffected renal urea clearance in our urea-infused sheep.

The changes of the plasma levels of both potassium and magnesium could be explained as a result of the renal excretion of these electrolytes due to urea load. Though the changes in the potassium or magnesium excretion were just under the significance levels the tendency was quite clear. The higher excretion of sodium seems to be a consequence of sharp change in the osmotic parameters of tubular fluid like during osmotic diuresis and it may be related also to a function of the specific sodium-dependent urea transporter during urea load (Is ozaki et al. 1994). The findings of the increase in plasma and urine osmolality and of osmotic clearance are evidently caused by larger amounts of urea.

In conclusion, the results of this experiment demonstrate that the kidneys of sheep with formation of rather hypotonic urine during intake of a high protein diet do not respond to an intravenous urea load with a rise in the GFR nor a change of the urea clearance.

\section{Funkcia obličiek u oviec s infúziou močoviny počas príjmu vysokobielkovinovej diéty}

Cielmi tohto experimentu bolo skúmat účinky zvýšenia koncentrácie močoviny v plazme intravenóznou infúziou na renálne funkcie, obzvlášt na glomerulárnu filtráciu (GFR) u oviec, ktoré počas príjmu vysokobielkovinovej diéty netvorili hypertonický moč. Mladé ovce s hmotnostou 22-25 kg dostávali diétu s denným príjmom 129,3 g hrubého proteínu a 12,03 MJ strávitelnej energie počas 3 týždňov pred meraniami renálnych funkcií. $\mathrm{V}$ priebehu clearance protokolu bola hladina močoviny $\mathrm{v}$ plazme zvýšená infúziou do v. jugularis takmer trojnásobne oproti základným hodnotám (z 5,67 \pm 0,48 na 15,70 \pm 0,79 $\left.\mathrm{mmol} \cdot \mathrm{l}^{-1}, \mathrm{P}<0,001\right)$. Močovinová zátaž nemala vplyv na vylučovanie moča $(3,07 \pm 0,41$ vs. $\left.2,40 \pm 0,23 \mathrm{ml} \cdot \mathrm{min}^{-1}, \mathrm{NS}\right)$ ani na GFR $\left(81,43 \pm 8,14\right.$ vs. $\left.77,48 \pm 5,43 \mathrm{ml} \cdot \mathrm{min}^{-1}, \mathrm{NS}\right)$. Samozrejme, koncentrácia močoviny v moči $\left(79,84 \pm 17,16\right.$ vs. $243,22 \pm 18,94 \mathrm{mmol} \cdot \mathrm{l}^{-1}$, $\mathrm{P}<0,001)$ a množstvo vylúčenej močoviny $\left(198,78 \pm 9,17\right.$ vs. 586,60 $\pm 69,69 \mu \mathrm{mol} \cdot \mathrm{min}^{-1}$, $\mathrm{P}<0,001)$ spolu s clearance osmoticky aktívnych látok $\left(1,87 \pm 0,11\right.$ vs. $3,85 \pm 0,52 \mathrm{ml} \cdot \mathrm{min}^{-1}$, $\mathrm{P}<0,01)$ boli štatisticky významne zvýšené u zvierat s infúziou močoviny. Vysoká hladina močoviny $\mathrm{v}$ plazme mala zretelne za následok zvýšenie reabsorbcie močoviny (z 245,22 $\pm 34,55$ na $\left.636,02 \pm 67,17 \mu \mathrm{mol} \cdot \mathrm{min}^{-1}, \mathrm{P}<0,001\right)$, avšak bez zmien vo frakčnej exkrécii močoviny $(47,26 \pm 4,23$ vs. $47,49 \pm 3,34 \%$, NS) alebo v clearance močoviny $(36,20 \pm 2,16$ vs. $36,80 \pm 3,52 \mathrm{ml} \cdot \mathrm{min}^{-1}$, NS). Uvedené výsledky ukazujú, že obličky oviec tvoriace počas príjmu vysokobielkovinovej diéty skôr hypotonický moč neodpovedajú na intravenóznu infúziu močoviny zvýšením GFR alebo zmenou v renálnom clearance močoviny.

Acknowledgements

This study was supported by the Grant Agency for Science VEGA of the Slovak Republic, grant No. 4158/99.

\section{References}

BANKIR, L., BOUBY, N., TRINH-TRANG-TAN, M. M., AHLOULAY, M., PROMENEUR, D. 1996: Direct and indirect cost of urea excretion. Kidney Int. 49: 1598-607 
BANKIR, L. 1996: Urea and the kidney. In: The Kidney. Ed.: B. M. Brenner. Saunders, Philadelphia, 571-606 BANKIR, L., MARTIN, H., DECHAUX, M., AHLOULAY, M. 1997: Plasma cAMP: A hepatorenal link influencing proximal reabsorption and renal hemodynamics? Kidney Int. 51: S50-S56

BOLDIŽÁROVÁ, K., FAIX, Š., LENG, L. 1999: The renal response of sheep fed a high protein diet to treatment with vasopressin analogue. Acta Vet. Brno 68: 99-104

CIRIO, A., BOIVIN, R. 1990: Urea recycling from the renal pelvis in sheep: a study with $\left[{ }^{14} \mathrm{C}\right]$ urea. Am. J. Physiol. 258: F1196-F1202

FAIX, Š., SILVA, R., BOIVIN, R. 1994: Effects of glucagon on diuresis, renal plasma flow and glomerular filtration in sheep. Vet. Res. 25: 51-56

FAIX, S., LENG, L. 1997: The renal response of sheep to intraportal infusion of glucagon. Exp. Physiol. 82: 10071013

FAIXOVÁ, Z., LEVKUT, M, KOLODZIEYSKI, L., FAIX, Š., LENG, L. 1998: The distribution of enzymes in the kidneys of sheep fed a high and low protein diet. Acta Vet. Brno, 67: 83-87

HIRSCHBERG, R. R., ZIPSER, R. D., SLOMOWITZ, L. A., KOPLLE, J. D. 1988: Glucagon and prostaglandins are mediators of amino acid-induced rise in renal hemodynamics. Kidney Int. 33: 1147-1155

ISOZAKI, T., LEA, J. P., TUMLIN, J. A., SANDS, J. M. 1994: Sodium-dependent net urea transport in rat initial inner medullary collecting ducts. J. Clin. Invest. 94: 1513-1517

LANG, F., TSCHERNKO, E., OTTL, I., SCHULZE, E., HALLBRUCKER, C., HÄUSSINGER, D. 1991: Hepatorenal reflex regulating kidney function. Hepatology 14: 590-594

LEE, K. E., SUMMERILL, R. A. 1982: Glomerular filtration rate following administration of individual amino acid in conscious dogs. Q. J. Exp. Physiol. 67: 459-465

LENG, L., SZANYIOVÁ, M., BOĎA, K. 1985: The renal response of sheep to a low dietary nitrogen intake. Physiol. Bohemoslov. 34: 147-159

LENG, L., SZANYIOVÁ, M., FAIX, Š., VÁRADY, J., BOĎA, K. 1986: Simple fluorometric ultramicroassay for urea in tubular fluid of the kidney. Pflügers Archiv 406: 648-650

LENG, L., SZANYIOVÁ, M., FAIX, Š., CIRIO, A. 1994: Renal response of sheep fed a low protein diet to intraportal infusion of arginine and glycine. Comp. Biochem. Physiol. 108A: 343-347

SKRZYPCZAK, W. F., OZGO, M., JANUS, K., SKOTNICKA, E., JANKOVIAK, D., MUSZCZYNSKI, Z., SUSZYCKA, J. 1996: The influence of increased protein content in the diet on renal function in calves. Acta Vet. Brno, 65: 115-121

SZANYIOVÁ, M., FAIX, Š., LENG, L. 1996: Delivery of protein to abomasum and renal functions in sheep. Abstracts of the XVI International Symposium of Animal Physiology, November 22-24, 1995, Třešt, Živočišna výroba, 41: 37

VUREK, G., PEGRAM, S. 1966: Fluorometric method for the determination of nanogram quantities of inulin. Analyt. Biochem. 16: 409-419 